\title{
Impact of consumer Attitude towards purchase intention of the counterfeit products: a multigroup analysis between the user and non-user
}

DOI: $10.35530 / I T .072 .06 .20203$

\author{
AMJAD FIZA \\ ZIR-UR-REHMAN MUHAMMAD \\ HASHIM MUHAMMAD \\ BAIG SAJJAD
}

MUBARIK FAZAL

IQBAL SHAHZAD

HAKEEM UR REHMAN

\begin{abstract}
REZUMAT
Impact of consumer Attitude towards purchase intention of the counterfeit products: a multigroup analysis between the user and non-user

The purpose of this study was to investigate the factors which influence a consumer's decision to buy counterfeit products. The factors are Attitude towards counterfeits by economic benefit, Attitude towards counterfeits by Hedonic benefits, Subjective norm and Perceived behaviour control and their impact on the purchase intention of the textile/clothing counterfeit product was analysed. A total of 120 questionnaires were distributed. Data was analysed using IBM Statistics 3.0. and SMART PLS. Attitude towards counterfeits by economic benefit and Perceived behaviour control had strong relationships with purchase intention of counterfeit products. Attitude towards counterfeits by Hedonic benefits didn't show any significant relationship with purchase intention. Subjective norm had strong positive relationship with purchase intention of counterfeits. This study is useful for Developing Countries, especially in Impact of theory of planned behaviour on the purchase intention of the counterfeits and is examined on the user and non-user of the counterfeit product.
\end{abstract}

Keywords: Hedonic benefits, Subjective norm, Perceived behaviour control, purchase intention, counterfeit products

Impactul atitudinii consumatorului față de intenția de cumpărare a produselor contrafăcute: o analiză multigrup între utilizator și non-utilizator

Scopul acestui studiu a fost de a investiga factorii care influențează decizia consumatorului de a cumpăra produse contrafăcute. Factorii sunt Atitudinea față de produse contrafăcute prin beneficii economice, Atitudinea față de produse contrafăcute prin Beneficii hedonice, Norma subiectivă și Controlul comportamentului perceput și s-a analizat impactul acestora asupra intenției de cumpărare a produsului de îmbrăcăminte contrafăcut. Au fost distribuite în total 120 de chestionare. Datele au fost analizate utilizând IBM Statistics 3.0. și SMART PLS. Atitudinea față de produse contrafăcute prin Beneficiul economic și Controlul comportamentului perceput au avut relații puternice cu intenția de cumpărare a produselor contrafăcute. Atitudinea față de produsele contrafăcute prin Beneficii hedonice nu a arătat nicio relație semnificativă cu intenția de cumpărare. Norma subiectivă a avut o relație puternică pozitivă cu intenția de cumpărare a produsului contrafăcut. Acest studiu este util pentru țările în curs de dezvoltare, în special în Impactul teoriei comportamentului planificat asupra intenției de cumpărare a produselor contrafăcute și este analizat pe utilizatorul și non-utilizatorul produsului contrafăcut.

Cuvinte-cheie: Beneficii hedonice, Norma subiectivă, Controlul comportamentului perceput, intenția de cumpărare, produse contrafăcute

\section{INTRODUCTION}

Counterfeit product is a worldwide concern that causes major economic and social problems [1]. The trade of counterfeit product is calculated at $\$ 500$ billion worldwide and it is around $5 \%$ to $7 \%$ of the all world trades [2]. However $\$ 268.2$ (63\%) billion represents the U.S. trade share of the counterfeit goods [3]. While ICC (International Anti-counterfeiting Coalition) stated in its report that loss of more than $\$ 200$ billion and 75000 jobs in United States is due to the counterfeit goods and piracy [4]. New York have annual estimated sale of the counterfeit good of $\$ 23$ billion and this causes $\$ 1$ billion decrease in tax revenue annually [3]. Counterfeit goods are a major threat for new arrival brand product [5]. Due to high presence of counterfeit goods in the market, counterfeiting is a market which produces fake products similar to the original brank product. This fact increases the sale of the products at a shocking rate [6]. However, the Attitude towards counterfeit good that leads to the purchase intention of the counterfeit good lie in relation to the study of Liao et al. [7]. Many research and study focus on the purchase intention of the counterfeit goods but mostly should focus on the supply side of the counterfeit goods [8, 9]. While Pakistan is the biggest market for counterfeit goods, the quantity of 
research work done on the other part of demand supply is insufficient. The government authority and manufacturing work to detain this unlawful activity, but counterfeiting is present in the market because its sale exists. The current study focuses on: (a) to identify the Subjective norm that affects consumer motivation towards the purchase of the fashion counterfeit goods; (b) to identify the Attitude towards the counterfeits by economic benefit and used theory of planned behaviour to identify the relationship between subjective and perceived behaviour control towards the purchase of the textile/clothing counterfeit goods; (c) to identify the effect of the past purchase behaviour on the purchase intention of the fashion counterfeit goods.

\section{LITERATURE REVIEW}

\section{The demand for counterfeit goods}

The study of the counterfeit goods is growing rapidly throughout the world. There are many predictors of the counterfeits which have identified the impact of the buying intention of the counterfeits, such as Subjective norm (social status, social cost and value consciousness) [10]. While Perceived behaviour control is made-up to imitate user of the product. Counterfeits are the market and the manufacturing of the product which looks similar to the original product [6]. However, the ever consumption of the different variable such as economic, social and political and implications of the marketing in this field have attracted researchers.

\section{Purchase intention of the counterfeit product}

The most popular way to examine the purchase intent of the counterfeit good is the attitude of the consumer towards the counterfeit goods [11] describe attitude as an "a person's overall evaluation concept". It is also referred to be the portion of a person's character. Researchers argue that consumer education about the counterfeit can improve this situation to overcome the counterfeits sale [12-14]. The planned behaviour theory suggested that attitude should be coupled with the Subjective norm and Perceived behaviour.

\section{Attitude towards counterfeits by economic benefits}

"Attitude is defined as the mental state individuals use to structure the ways to perceive the environment" $[15,16]$. Attitude can either be positive or negative. Positive Attitude towards the counterfeit product influences the consumer's Attitude towards the second purchase of the counterfeit product.

H1: Impact of Attitude towards counterfeits by economic benefits on the purchase intention of the counterfeits.

\section{Attitude towards counterfeits by Hedonic benefits}

Attitude is an aspect to forecast intentions and behaviour of customers [14,15-18]. The Attitude towards counterfeit goods is also seen as a factor and has an important influence to the idea of buying counterfeit goods $[19,20]$. So the Attitudes towards counterfeit goods are a dynamic factor to predict the intention of buying counterfeit goods, especially for Hedonic benefits [21]. There is a positive relationship between favourable attitudes and intention to purchase towards counterfeiting goods [18-26].

H2: Impact of Attitude towards counterfeits by Hedonic benefit on the purchase intention of the counterfeits.

\section{Subjective norm}

The correlation between Subjective norms and Attitudes towards behaviour was examined more thoroughly, and tested the causal link from norms to attitudes. Chang [27] suggested that the link could be explained with social environment's influence on an individual's attitude formation. Subjective norm is a social factor referring to the perceived social pressure to perform or not to perform a given behaviour [18]. Consumers may be informationally susceptible, when expertise from others influences their choice (e.g. when one does not know the product category), and also normatively susceptible, when they are more interested in making a good impression to others [28].

H3: Impact of the Subjective norm on the purchase intention of the counterfeit product.

\section{Perceived behaviour control}

Perceive behaviour control has less impact on the purchase intention. The e-commerce has reduced the importance of the Perceived behaviour control as many consumers of the counterfeit product buy them from the internet. Ajzen [18] added an additional variable, Perceived behavioural control, to the original TRA model to address this problem. Perceived behavioural control is individual's perception of their ability to engage in the certain behaviour [18]. Perceived behavioural control is a combination of control beliefs and perceived power. Control beliefs are the presence of opportunities or resources for facilitating or interrupting the performance of behaviour [18].

H4: Impact of the Perceived behaviour control on the purchase intention of the counterfeits.

\section{Theoretical framework}

Theory of planned behaviour [18] describes how an individual's made Attitude towards purchased behaviours. In this theory, intentions are defined as act towards any product in specific way [17] and Subjective norms refer to perceived social pressure to perform or not performs the behaviour [18]. This study uses four independent variables i.e., Attitude towards counterfeits by economic benefit (ATCEB), Attitude towards the counterfeits by Hedonic benefits (ATCHB), Purchased behaviour control (PBC) and Subjective norm (SN). While the moderator variables are past purchase (figure 1). 


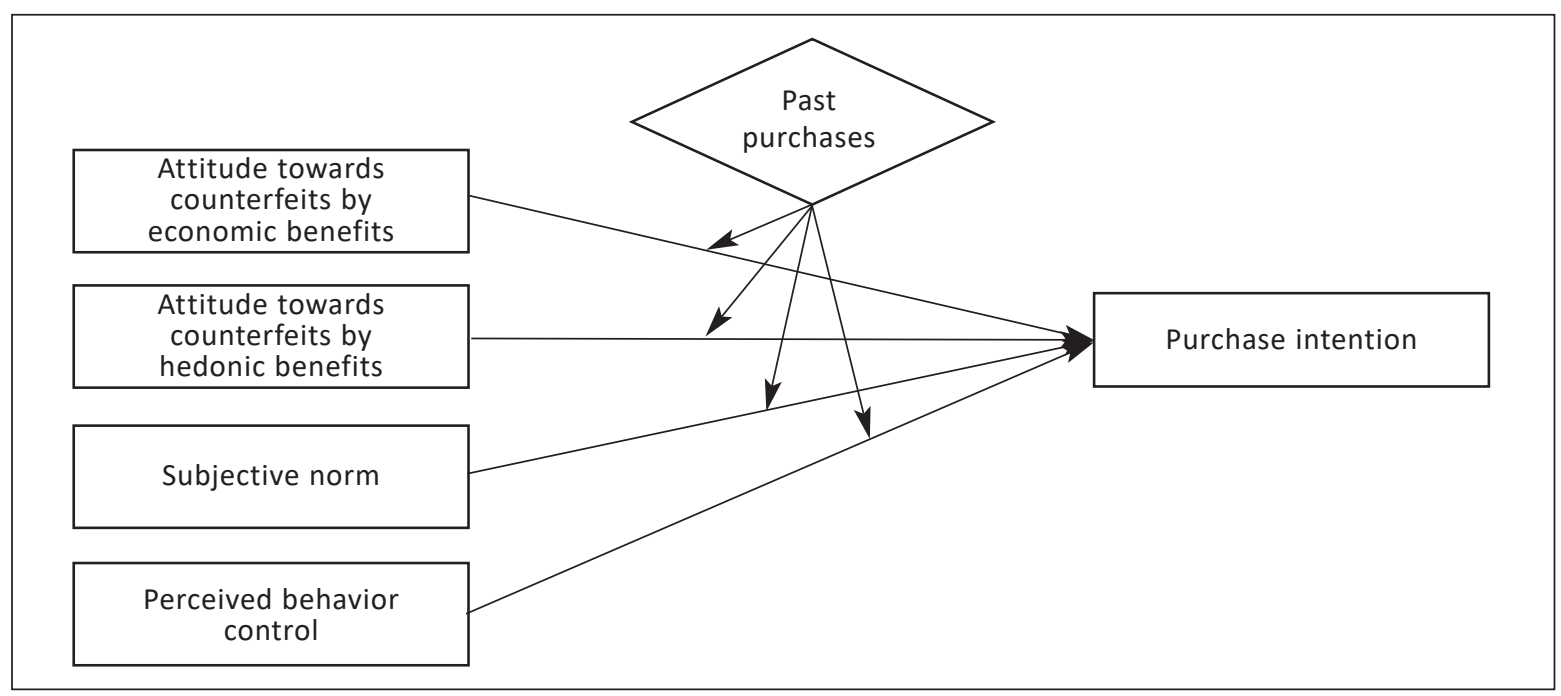

Fig. 1. Theoretical frame work

\section{METHODOLOGY}

The study used quantities research methodology. For this purpose, primary data was collected from the 250 consumers, who used counterfeit product to know their buying experience after purchasing one time counterfeits product in Pakistan.

The questionnaire used five scales that included (5 = strongly agree, 4 = agree, $3=$ neutral, 2 = disagree and $1=$ strongly agree). However, Attitude towards counterfeits by economic benefit and Hedonic benefit are measured by Kirkwood-Mazik [29]. Subjective norm was measured by the Marcoux et al. scale [30]. Three product design were developed for this study. Perceived behaviour was measured by the Lichtenstein et al. [31]. Past purchase behaviour was measured by nominal scale $(0=$ No, $1=$ Yes $)$. Purchase intent (PI) for counterfeit goods was measured using five items that were adapted from Beck and Ajze [32].

\section{PROCEDURE FOR DATA ANALYSIS}

Statistics analysis was done at National Textile University, Faisalabad Pakistan. The supervisor and the researcher were involved in the planning, analysing and execution of data analysis. Data was analysed by using descriptive statistics. IBM SPSS Statistics was used to analyse data. For exact relationship among variable, validity of construct is extremely important and it is depended upon the researcher ability to properly measure the variable.

\section{Data analysis and result}

Below tables shows that different variable dependent, moderating variable and independent variables. These variables should be used to find the answer of the research question.

\section{Reliability and validity analysis}

The reliability of this model was checked through the factor loading and composite reliability. All the value of the factor loading and composite reliability should be exceeded from the minimum value that is 0.7 . The validity of model assessed through convergent validity and discriminant validity. However, the convergent validity model was determined by $A V$ and $C R$, all value of $C R$ and AVE must be greater than 0.5 and 0.7 respectively (figure 2 ).

\section{Discriminant validity}

For discriminant of the variables researcher have taken the square root of each value to find the AVE average variance extended that exceeded the intercorrelation developed with inter-correlation of the developed with alternate forum in the model to guarantee discernment validity (table 1) [33].

\begin{tabular}{|c|c|c|c|c|c|}
\hline \multicolumn{7}{|c|}{ DISCRIMINATE VALIDITY } \\
\hline Variables & CEB & CHB & PBC & PI & SN \\
\hline CEB & 0.780 & & & & \\
\hline CHB & 0.748 & 0.758 s & & & \\
\hline PBC & 0.757 & 0.708 & 0.690 & & \\
\hline PI & 0.768 & 0.645 & 0.724 & 0.732 & \\
\hline SN & 0.716 & 0.745 & 0.640 & 0.672 & 0.769 \\
\hline
\end{tabular}

\section{Structural model estimation}

According to Hair et al. [34] and Henseler et al. [35], the $\mathrm{R}^{2}$ is a measure of the predictive accuracy of the model. While according to Hair et al. [36], the Cross Validated redundancy $\mathrm{Q}^{2}$ method should be used for measuring predictive Relevance of inner model. While contrasting the $Q^{2}$ IS greater than zero is indicative for a specific inductive of whatever an endogenous build can be anticipated, it does not say anything about the quality of the prediction (table 2 and figure 3 ).

Table 2

\begin{tabular}{|c|c|c|}
\hline \multicolumn{3}{|c|}{ STRUCTURAL MODEL ESTIMATION } \\
\hline Variables & R Square & R square adjusted \\
\hline PI & 0.654 & 0.643 \\
\hline
\end{tabular}




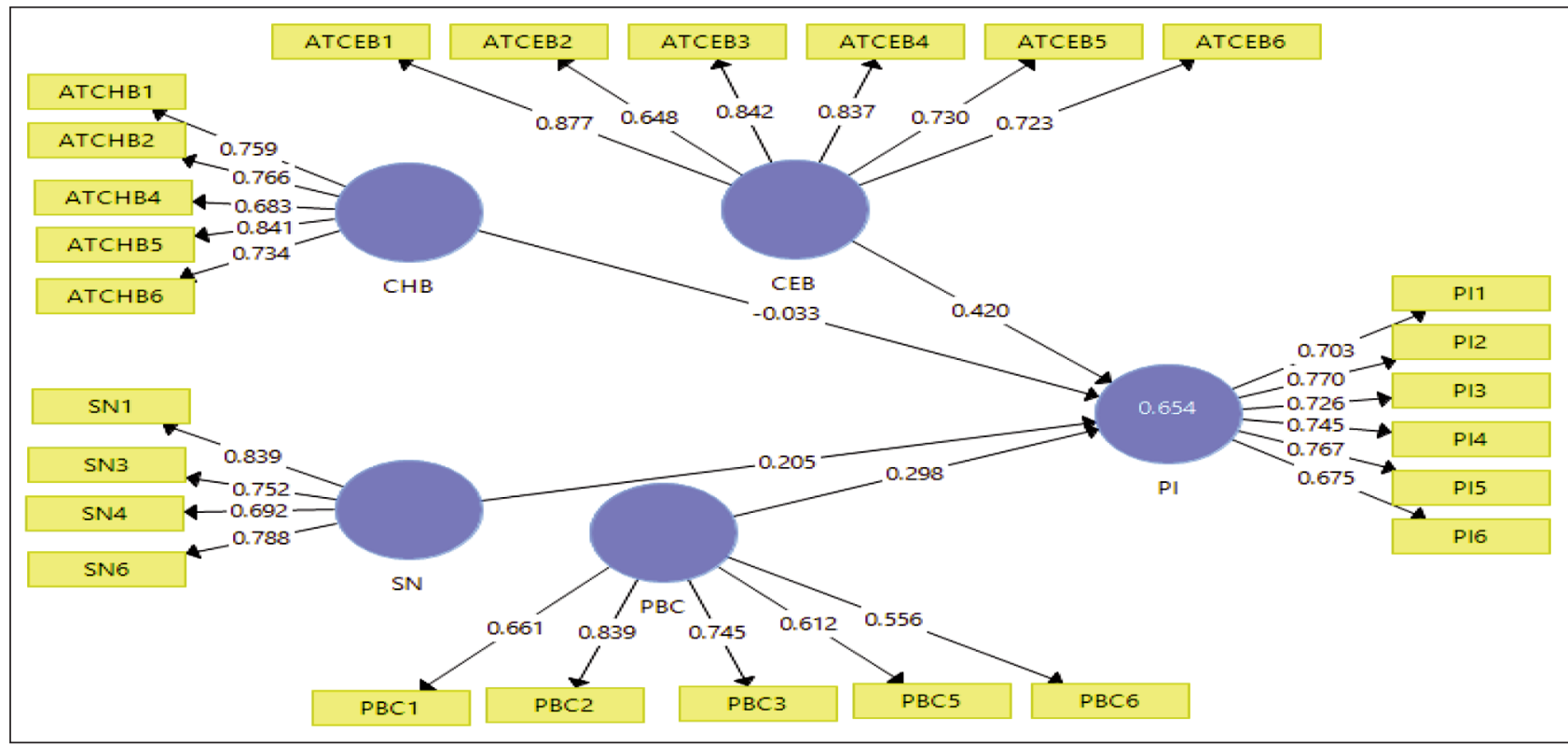

Fig. 2. Reliability analysis

\section{Complete (user and non-user of counterfeits)}

The impacts of Attitude towards counterfeits have economic benefits on the purchase intent of the counterfeit product. However, table 3 illustrates the finding of the H1. Hypothesis 1 is that impact of the Attitude of the counterfeits by economic benefit on the purchase intent of the counterfeit product, as per our finding ATCEB have a significant impacts on the purchase intent of the counterfeit product showing Hypothesis 1 was supported $(\beta=0.420$, $t$-value $=0.417$ and $p$-value $=0.002$ ).

Hypothesis 2 the Attitude towards counterfeits by Hedonic benefit has impacts on the purchase intent of the counterfeit product. As per finding ATCHB has significant no impact on the purchase intent of the counterfeit product. Hypothesis 2 was not supported $(\beta=-0.03, t$-value $=-0.024$ and $p$-value $=0.844)$. Hypothesis 3 the Subjective norm of the counterfeits

\begin{tabular}{|c|c|c|c|}
\hline \multicolumn{4}{|c|}{ FINDING OF THE H1 } \\
\hline Hypothesis & Complete & User & Non-user \\
\hline $\mathrm{ATCEB} \rightarrow \mathrm{PI}$ & 0.417 & 0.615 & 0.127 \\
\hline $\mathrm{ATCHB} \rightarrow \mathrm{PI}$ & 0.033 & -0.0273 & 0.235 \\
\hline $\mathrm{SN} \rightarrow \mathrm{PI}$ & 0.205 & 0.251 & 0.229 \\
\hline $\mathrm{PBC} \rightarrow \mathrm{PI}$ & 0.298 & 0.354 & 0.259 \\
\hline
\end{tabular}

has impact on the purchase intent of the counterfeit product. As per finding SN has significant impact on the purchase intent of the purchase intent of the counterfeit product. Hypothesis 3 was supported $(\beta=0.205, t$-value $=0.199$ and $p$-value $=0.013)$. Hypothesis 4 the Perceived behaviour control of the counterfeits has impacts on the purchase intent of the counterfeit product. As per finding PBC has

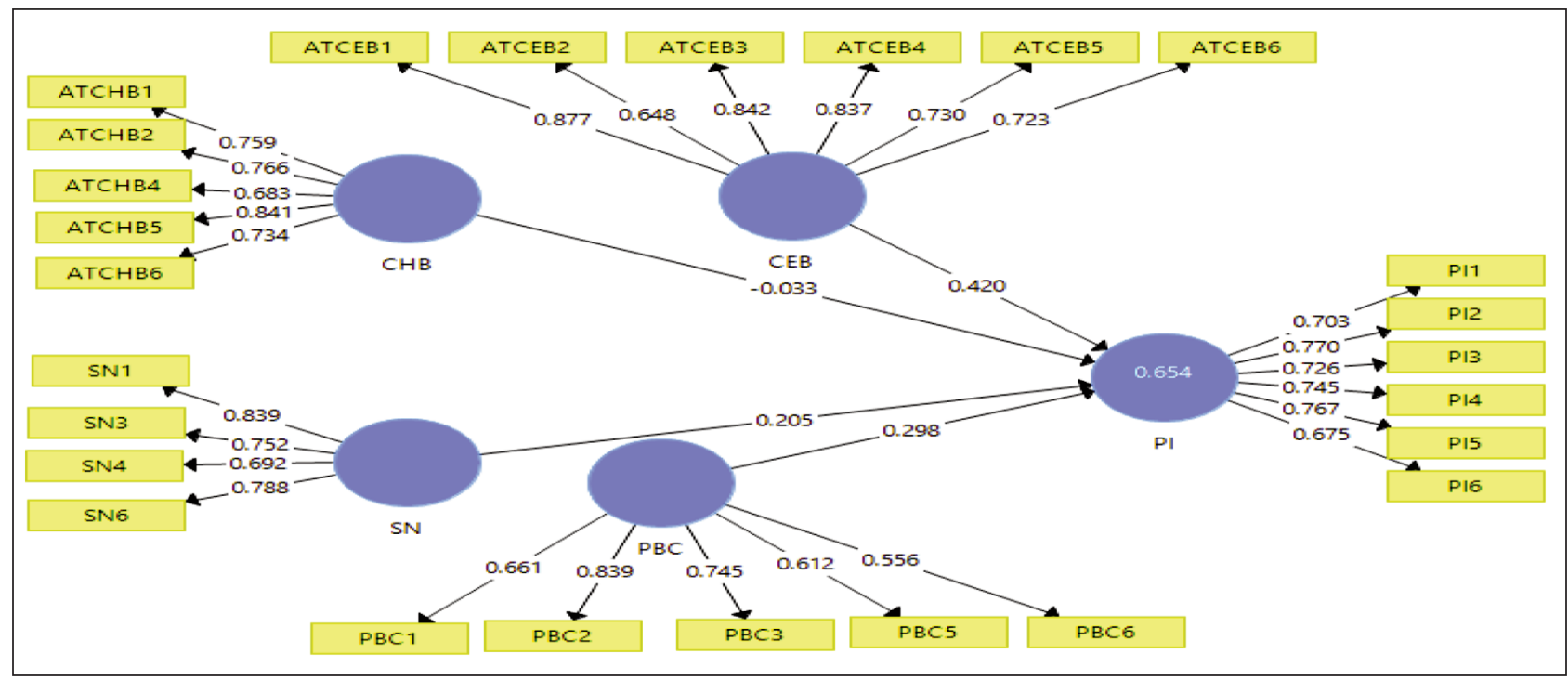

Fig. 3. PLS-Bootstrapping 


\begin{tabular}{|c|c|c|c|c|c|}
\hline \multicolumn{7}{|c|}{ HYPOTHESIS RELATIONSHIP } \\
\hline Hypothesis & Path coefficient & t-value & p-value & Excepted impact & Decision \\
\hline H1 & 0.420 & 0.417 & 0.02 & + & Supported \\
\hline H2 & -0.033 & -0.024 & 0.844 & - & Not supported \\
\hline H3 & 0.205 & 0.199 & 0.013 & + & Supported \\
\hline H4 & 0.298 & 0.3 & 0 & + & Supported \\
\hline
\end{tabular}

significant impact on the purchase of the counterfeit product. Hypothesis 4 was supported $(\beta=0.289$, $\mathrm{t}$-value $=0.300$ and $p$-value $=0.000)($ table 4$)$.

\section{DISCUSSION AND CONCLUSION}

As predictable finding of the current study has identified the impact of ATCEB, SN and PBC have a significant on the purchase intention of the counterfeits. Consumer may made purchase intention towards the fashion counterfeits because the Perceived behaviour may look similar to the authentic goods. People who purchase fashion counterfeits in the past have positive Attitude towards buying the buying fashion counterfeits. The result suggests that people may buy fashion counterfeits usually. Gentry et al. [37] found that tourists, both Caucasians and Asians, are the main customers of fashion counterfeit goods.

When buying fashion counterfeits becomes habitual, it may be further difficult to depress the behaviour. Therefore, it is significant for the government and authorities to bound opportunities and resources (counterfeit selling district) to buying fashion counterfeit goods. The U.S. Custom may develop an educational movement at the airports to deliver people an opportunity to think about ethical matters and negative concerns related to counterfeit goods.

The sale of the counterfeits is large due to large scale of counterfeits present in a market. It is difficult to control them and controlling scale of the counterfeits causes loss of the millions of the job that are associated either the sale and the purchase of the fashion counterfeits. This finding is reliable with earlier studies that inspected other product groups such as music CDs, clothing, and software [18, 34-40].

This finding clearly implies that counterfeit consumers are very probable to become final consumers for originals completed time and do not return to counterfeits, a possibility that is reliably found in pirated software or illegal music file transferring research, where counterfeits assistance a full and fast market diffusion of the prototypes [41]. Similarly, fashion counterfeits might function as a risk-free trial form, make attention among customers, and make them feast positive word-of-mouth to other consumers.

It is been for a long time that counterfeits manufacturing supply has been under examination and the people and the institution finding a way to overcoming this activity. But now researcher has shifted their focus that if counterfeit product is produced in the large rate, then it means its demand exist. This study focuses on the consumer's attitude and purchase intention of the counterfeits. This study was based on the user and the non-user of the counterfeit product. For this purpose, a model was adapted which had three independent variables, namely Attitude towards the counterfeits by economic benefit, Attitude towards the counterfeits by Hedonic benefit and subjective and the other is Perceived behaviour control with a moderator past purchase and the dependent variables is purchase intention of the counterfeit product. To produce results that provide dynamic information, broad literature has been presented that supports this study and gives comprehensive base. On the other hand, effective analysis techniques have been discussed in methodology section to increase the validity of this study. This study concluded that Attitude towards counterfeits by economic benefit and Perceived behaviour control had strong relationships with purchase intention of counterfeit products. Attitude towards counterfeits by Hedonic benefits didn't show any significant relationship with purchase intention. Subjective norm had strong positive relationship with purchase intention of counterfeit. Conceptual framework in this study was adapted from exploratory study of Kim and Karpova [42] and this study tested the prepositions given in that study and also explored other relationships.

\section{CONTRIBUTION OF STUDY}

The current research has several contributions in the context of original textile brand producers and local users, as well as also helps the policy makers to fight against the increasing trends of sale of duplicating goods, hindering the safety and financial condition of the country. The study contributed to the general public and the consumer of the counterfeit product focusing not only the purchase intention of the counterfeit product but also change in customer buying behaviour after the first purchase of the counterfeit product. Consumer past purchase behaviour has a positive Attitude towards buying the fashion counterfeits, endorsing the consequences of d'Astous and Saint-Louis [43]. This research helps the government and the brand to know the factor behind the purchase of the counterfeit product. This will also help the private brand to fight against the counterfeit product. By investigating the factor behind the purchase of the counterfeit product, private enterprises can have increased the sale of their brand by improving it. In this study Hedonic benefit signifies the impact of the 
purchase intention of the counterfeit product. An importance that consumer who buy counterfeit luxury product he can get pleasure for some time but they don't give long time pleasure to customer as compared to brand product provided.

\section{LIMITATION OF THE STUDY}

For the future research, the current study also has procedural limitations. Firstly, data in this study was collected only from the students, who studied in the public University of the Faisalabad. It can be an issue of generalizability, because the students of the public university sector in Pakistan may have changed
Attitude towards the purchase intention of the counterfeit product. It would be valuable to conduct crosscultural and cross-industrial studies to identify the cultural influence among variables. Secondly, the study used cross section data which creates a problem on defining the cause and effect relationship between variables. Lastly, the niumber of students from the public university sector is equaly important as the number of students from the private university sector. Therefore, it is important to compare the relationship between the public and the private university customers of textile/clothing counterfeit products.

\section{REFERENCES}

[1] Gilgoff, H., Counterfeiting causes problems for companies, taxpayers, consumers, In: News-day, 2004

[2] Johnson, B.T., Eagly, A.H., Effects of involvement on persuasion: A meta-analysis, In: Psychol. Bull., 1989, 106, 2, 290

[3] Tucker, R., Battling counterfeits: Divulging the danger of $\$ 500$ b global industry, In: Women's Wear Dly., 2005, 1-2

[4] Cook, D., Writer, S., Fake goods, real problem, In: Chattanooga Times Free Press, 2006

[5] Oldenburg, D., Counterfeit goods that trigger the "false" alarm, In: Washington Post, 2005

[6] Penz, E., Stottinger, B., Forget the Areal@ thingbtake the copy! An explanatory model for the volitional purchase of counterfeit products, In: ACR North Am. Adv., 2005

[7] Liao, C.-H., Hsieh, I.-Y., Determinants of consumer's willingness to purchase gray-market smartphones, In: J. Bus. ethics, 2013, 114, 3, 409-424

[8] Bamossy, G., Scammon, D.L., Product counterfeiting: consumers and manufacturers beware, In: Adv. Consum. Res., 1985, 12, 1

[9] Bush, R.F., Bloch, P.H., Dawson, S., Remedies for product counterfeiting, In: Bus. Horiz., 1989, 32, 1, 59-66

[10] Edwards, K.E., Carpenter, J.M., US Consumer Attitudes toward Counterfeit Fashion Products, In: J. Text. Apparel, Technol. Manag., 2013, 8, 1

[11] Peter, J.P., Olson, J.C., Consumer Behavior and Marketing Strategy, McGrawHill, Boston, 2008, 130

[12] Norum, P.S., Cuno, A., Analysis of the demand for counterfeit goods, In: J. Fash. Mark. Manag. An Int. J., 2011

[13] Khalid, M., Rahman, S.U., Word of mouth, perceived risk and emotions, explaining consumers'counterfeit products purchase intention in a developing country: implications for local and international original brands, In: Adv. Business-Related Sci. Res. J., 2015, 6, 2, 145-160

[14] Jiang, Y., Miao, M., Jalees, T., Zaman, S.I., Analysis of the moral mechanism to purchase counterfeit luxury goods: evidence from China, In: Asia Pacific J. Mark. Logist., 2019

[15] Chaudary, M.W.T., Ahmed, F., Gill, M.S., Rizwan, M., The determinants of purchase intention of consumers towards counterfeit shoes in Pakistan, In: J. Public Adm. Gov., 2014, 4, 3, 20-38

[16] Jiang, Y., Xiao, L., Jalees, T., Naqvi, M.H., Zaman, S.I., Moral and ethical antecedents of toward counterfeit luxury products: evidence from Pakistan, In: Emerg. Mark. Financ. Trade, 2018, 54, 15, 3519-3538

[17] Fishbein, M., Ajzen, I., Belief, attitude, intention, and behavior: An introduction to theory and research, 1977

[18] Ajzen, I., The theory of planned behavior, In: Organ. Behav. Hum. Decis. Process., 1991, 50, 2, 179-211

[19] Usmani, S., Ejaz, A., Consumer Buying Attitudes towards Counterfeit and Green Products: Application of Social Comparison Theory and Materialism, In: South Asian J. Manag., 2020, 14, 1, 82-103

[20] Phau, I., Sequeira, M., Dix, S., Consumers' willingness to knowingly purchase counterfeit products, In: Direct Mark. An Int. J., 2009

[21] Nordin, N., A study on consumers' attitude towards counterfeit products in Malaysia, University Malaya, 2009

[22] Ang, S.H., Cheng, P.S., Lim, E.A.C., Tambyah, S.K., Spot the difference: consumer responses towards counterfeits, In: J. Consum. Mark., 2001

[23] Huang, J., Lee, B.C.Y., Ho, S.H., Consumer attitude toward gray market goods, In: Int. Mark. Rev., 2004

[24] De Matos, C.A., Ituassu, C.T., Rossi, C.A.V., Consumer attitudes toward counterfeits: a review and extension, In: J. Consum. Mark., 2007

[25] Phau, I., Teah, M., Devil wears (counterfeit) Prada: a study of antecedents and outcomes of attitudes towards counterfeits of luxury brands, In: J. Consum. Mark., 2009

[26] Nguyen, P.V., Tran, T.T.B., Modeling of Determinants Influence in Consumer Behavior towards Counterfeit Fashion Products, In: Bus. Manag. Dyn., 2013, 2, 12, 12

[27] Chang, M.K., Predicting unethical behavior: a comparison of the theory of reasoned action and the theory of planned behavior, In: J. Bus. ethics, 1998, 17, 16, 1825-1834

[28] Bearden, W.O., Netemeyer, R.G., Teel, J.E., Measurement of Consumer Susceptibility to Interpersonal Influence?, In: Journal of Consumer Research, 1990, 15, 473-481 
[29] Kirkwood-Mazik, H.L., An Inquiry into the Antecedents of Consumer Purchase of Non-Deceptive Counterfeit Goods: Theory, Practice and Problems, 2014

[30] Marcoux, J.-S., Filiatrault, P., Cheron, E., The attitudes underlying preferences of young urban educated Polish consumers towards products made in western countries, In: J. Int. Consum. Mark., 1997, 9, 4, 5-29

[31] Lichtenstein, D.R., Netemeyer, R.G., Burton, S., Distinguishing coupon proneness from value consciousness: An acquisition-transaction utility theory perspective, In: J. Mark., 1990, 54, 3, 54-67

[32] Beck, L., Ajzen, I., Predicting dishonest actions using the theory of planned behavior, In: J. Res. Pers., 1991, 25, 3, 285-301

[33] Fornell, C., Larcker, D.F., Evaluating structural equation models with unobservable variables and measurement error, In: J. Mark. Res., 1981, 18, 1, 39-50

[34] Hair, J.F., Ringle, C.M., Sarstedt, M., PLS-SEM: Indeed a silver bullet, In: J. Mark. theory Pract., 2011, 19, 2, 139-152

[35] Henseler, J., Ringle, C.M., Sinkovics, R.R., The use of partial least squares path modeling in international marketing, In: New challenges to international marketing, Emerald Group Publishing Limited, 2009, 277-319

[36] Hair Jr, J.F., Sarstedt, M., Hopkins, L., Kuppelwieser, V.G., Partial least squares structural equation modeling (PLSSEM) An emerging tool in business research, In: Eur. Bus. Rev., 2014, 26, 2, 106-121

[37] Gentry, J.W., Putrevu, S., Shultz, C.J., The effects of counterfeiting on consumer search, In: J. Consum. Behav. An Int. Res. Rev., 2006, 5, 3, 245-256

[38] Bloch, P.H., Bush, R.F., Campbell, L., Consumer 'accomplices' in product counterfeiting: a demand side investigation, In: J. Consum. Mark., 1993

[39] Higgins, R.S., Rubin, P.H., Counterfeit goods, In: J. Law Econ., 1986, 29, 2, 211-230

[40] Tom, G., Garibaldi, B., Zeng, Y., Pilcher, J., Consumer demand for counterfeit goods, In: Psychol. Mark., 1998, 15, $5,405-421$

[41] Haruvy, E., Mahajan, V., Prasad, A., The effect of piracy on the market penetration of subscription software, In: J. Bus., vol. 77, 2004, S2, S81-S107

[42] Kim, H., Karpova, E., Consumer attitudes toward fashion counterfeits: Application of the theory of planned behavior, In: Cloth. Text. Res. J., 2010, 28, 2, 79-94

[43] d'Astous, A., Saint-Louis, O., National versus store brand effects on consumer evaluation of a garment, In: J. Fash. Mark. Manag. An Int. J., 2005

\author{
Authors: \\ AMJAD FIZA, ZIR-UR-REHMAN MUHAMMAD, HASHIM MUHAMMAD, \\ BAIG SAJJAD, MUBARIK FAZAL, IQBAL SHAHZAD, HAKEEM UR REHMAN
}

National Textile University, Faculty of Management Sciences, Main shaikhupura road 38000, Faisalabad, Pakistan e-mail: Fiza.amjad@hotmail.com, zia.msfin@iiu.edu.pk, hashimscu@gmail.com, fazaljutt50@gmail.com, shahzad.iqbaal@gmail.com, hakeem.rehman@gmail.com

\title{
Corresponding author:
}

\author{
BAIG SAJJAD
}

e-mail: sajjad.baig@hotmail.com 